\title{
PENGARUH KEMAMPUAN PEGAWAI, SARANA LAYANAN TERHADAP KUALITAS LAYANAN DAN KEPUASAN MASYARAKAT PADA KELURAHAN BATU PIRING KECAMATAN PARINGIN SELATAN
}

\author{
Wenny Lisninda \\ Sekolah Tinggi Ilmu Ekonomi Pancasetia Banjarmasin \\ Jl. Ahmad Yani Km. 5.5 Banjarmasin \\ wenny20578@gmail.com
}

\begin{abstract}
Abstrak: Wenny Lisninda, Npm.1911.32202.5052, Pengaruh Kemampuan Pegawai, Sarana Layanan Terhadap Kualitas Layanan Dan Kepuasan Masyarakat Pada Kelurahan Batu Piring Kecamatan Paringin Selatan, Kabupaten Balangan, Dibawah Bimbingan H.Ujianto Dan Yudi Rahman,2021. Tujuan penelitian untuk mengetahui dan menganalisis pengaruh kemampuan pegawai terhadap kualitas layanan,untuk mengetahui dan menganalisis pengaruh sarana layanan terhadap kualitas layanan, untuk mengetahui dan menganalisis pengaruh kemampuan pegawai terhadap kepuasan masyarakat, untuk mengetahui dan menganalisis pengaruh sarana layanan terhadap kepuasan masyarakat dan untuk mengetahui dan menganalisis pengaruh kualitas layanan berpengaruh signifikan terhadap kepuasan masyarakat pada Kelurahan Batu Piring Kecamatan Paringin Selatan Kabupaten Balangan. Populasi dari penelitian ini adalah masyarakatyang berurusan pada Kantor Kelurahan yang berusia sekitar 17 tahun sampai 50 tahun dan dengan total populasi dalam penelitian ini adalah sebanyak 5.983 orang responden dan sampel dalam penelitian 98 responden. Teknik pengolahan data menggunakan kuantitatif dan analisis dengan analisis jalur (path analysis) model mediasi dengan bantuan program SPSS (statistic produk service solution) Versi 17 for windows.Hasil penelitian uji hipotesis pertama dinyatakan bahwa variabel kemampuan pegawai berpengaruh signifikan terhadap kualitas layanan. uji hipotesis kedua dinyatakan bahwa variabel sarana layanan berpengaruh signifikan terhadap kualitas layanan, uji hipotesis ketiga dinyatakan bahwa variabel kemampuan pegawai berpengaruh signifikan terhadap kepuasan masyarakat, uji hipotesis keempat dinyatakan bahwa variabel sarana layanan berpengaruh signifikan terhadap kepuasan masyarakatdan hasil uji hipotesis kelima dinyatakan bahwa variabel kualitas layanan berpengaruh signifikan terhadap kepuasan masyarakat pada Kelurahan Batu Piring Kecamatan Paringin Selatan Kabupaten Balangan.
\end{abstract}

Kata Kunci : Kemampuan Pegawai, Sarana Layanan, Kualitas Layanan Dan Kepuasan Masyarakat 


\section{BAB I \\ PENDAHULUAN}

\subsection{Latar Belakang Masalah}

Aparatur Sipil Negara dirasakan semakin penting untuk menyelenggarakan pemerintahan dan pembangunan dalam usaha mencapai tujuan nasional yaitu mewujudkan masyarakat yang madani yang taat akan hukum, berperadapan modern, demokratis, makmur, adil dan bermoral tinggi. Kesiapan seluruh ASN baik itu kemampuan maupun kemauan yang tinggi sangat diharapkan didalam melaksanakan seluruh kegiatan organisasi serta menuntut adanya kinerja yang tinggi dari para pegawai. Perubahan paradigma pemerintah yang mengarah pada pemerintahan demokratis yang berazas pada good governance, diperlukan pula pembaharuan pada tataran aparatur pemerintah yang profesional. Berbicara profesionalisme Aparatur Sipil Negara merupakan hal yang sangat penting, karena dengan adanya profesionalisme pegawai, maka tugas dan fungsi organisasi dapat tercapai sesuai tujuan dengan misi secara optimal menurut standar tertentu yang telah diharapkan oleh organisasi itu sendiri maupun untuk berkepentingan masyarakat melalui pelayanan yang baik dan prima. Kelurahan adalah wilayah administratif di bawah Kecamatan. Kelurahan dipimpin oleh seorang Lurah yang berstatus sebagai Aparatur Sipil Negara (ASN). Kelurahan merupakan unit pemerintahanterkecil setingkat desa. Berbeda dengan desa Kelurahan memiliki hak mengatur wilayah walau terbatas. Berdasarkan Peraturan Pemerintah republik Indonesia Nomor 73 Tahun 2005 tentang Kelurahan, menjelaskan Kelurahan merupakan perangkat daerah Kabupaten/Kota yang berkedudukan di dilayah Kecamatan dan tugas dari Kelurahan adalah melaksanakan penyelenggaraan pemerintahan, pembangunan dan kemasyarakatan sedangkan fungsinya adalah (1) melaksanakan kegiatan pemerintahan kelurahan (2) pemberdayaan masyarakat (3) pelayanan masyarakat (4) pemeliharaan prasarana dan fasilitas pelayanan umum (5) pembinaan lembaga kemasyarakatan.Menurut Umar (2013:90) menjelaskan kemampuan merupakan kesanggupan melakukan sesuatu. Pemahaman sesuatu ini disesuaikan dengan posisi seseorang, jka ia seorang pegawai, maka sesuatu itu adalah pekerjaannya. Jadi kemampuan merupakan kesanggupan seorang pegawai untuk melakukan pekerjaan yang menjadi tanggung jawabnya.Sumber daya manusia adalah asset yang sangat berharga dan merupakan salah satu faktor penting dalam menunjang keberhasilan pelaksanaan kegiatan suatu organisasi. Kemampuan dalam menunjang aktivitas kerja diperlukan juga adanya sarana prasarana kerja. Sarana dan prasarana merupakan bentuk fasilitas pelengkap terhadap penunjang akan aktivitas kerja. Karena tanpa adanya sarana dan prasarana seperti fasilitas kerja tersebut maka aktivitas kerja yang dilaksanakan di akan berjalan kurang baik.Menurut Darsuni (2013:78) menjelaskan akan aktivitas para pegawai, di dalam kantor kelangsungannya pekerjaannya akan banyak dipengaruhi oleh kondisi dan situasi fisik, lingkungan dan fasilitas kerja yang tersedia. Oleh sebab itulah lingkungan fisik kantor berupa sarana dan prasarana harus dapat memenuhi dan mendukung interaksi yang terjadi, sehingga harmonisasi kehidupan kerja dapat berlangsung dengan baik dari permulaan masa kerja sampai akhir masa kerja akan dapat dicapai sesuai harapan. Secara umum sarana dan prasarana adalah alat penunjang keberhasilan suatu proses upaya yang dilakukan di dalam pelayanan publik, karena apabila kedua hal ini tidak tersedia maka semua kegiatan yang dilakukan tidak akan dapat mencapai hasil yang diharapkan sesuai dengan rencana. Menurut Muhdari (2011:35) menjelaskan proses pelayanan adalah suatu proses atau rangkaian kegiatan pelayanan atau rangkaian kegiatan pelayanan yang diberikan kepada pelanggan oleh bagian costumer service atau dari pihak perusahaan langsung dalam mempermudah dan memberikan kenyamanan kepada pelanggan. Sedangkan menurut Loina (2013:87) menjelaskan proses pelayanan adalah langkah dalam pembentukan citra dari perusahaan baik dengan melalui media berita, membentuk sebuah budaya perusahaan secara internal atau pun melakukan sebuah komunikasi mengenai pandangan perusahaan dengan berbagai tahap kerja.Kualitas layanan adalah kegiatan yang bertujuan memberikan pelayanan sebaik-baiknya kepada masyarakat yang selalu mengarah kepada kepuasan, hal ini dilakukan berdasarkan pertimbangan bahwa pandangan masyarakat yang pada umumnya berfokus pada tingkat kepuasan yang didapat selama menggunakan jasa yang 
ditawarkan. Profesionalisme dalam bekerja akan dapat mempengaruhi terhadap kualitas layanan yang diberikan bagi institusi yang mengelola dan menjual jasa. Peranan contact personel yang sangat penting dalam menentukan pelayanan, setiap instansi memerlukan pelayanan unggulan. Yang di maksud dengan pelayanan unggulan, yaitu suatu sikap cara memuaskan. Konsep mutu pelayanan secara tradisional hanya berfokus kepada aktivitas inspeksi untuk mencegah lolosnya produk cacat ketangan masyarakat.Menurut hasil penelitian Eigis Yani Pramulaso (2020), menyatakan secara simultan dan parsial kualitas pelayanan dan kinerja pegawai memiliki pengaruh signifikan terhadap kepuasan masyarakat dimana nilai Fhitung yang diperoleh sebesar 19.042 dan nilai sig 0,000.Berdasarkan hasil wawancara dengan Bapak H. Supianoor, S,sos selaku Lurah pada Kelurahan Batu Piring Kecamatan Paringin Selatan Kabupaten Balangan bahwa selama ini juga kerap kali dihadapkan belum optimalnya kemampuan pegawai dalam bekerja, yang mana selama ini terlihat saat bekerja masih ada pegawai yang belum menguasai perangkat eletronik seperti aplikasi dari program komputer yang berhubungan dengan program kerja, masih adanya pegawai yang kurang mengerti akan sistem administrasi operasional kerja, sehingga hal ini kerap kali menghambat jalannya pelayanan yang diberikan. Fenomena lain yaitu terkait sarana prasarana kerja yang belum menunjang terhadap kelancaran dan proses dalam bekerja maupun proses layanan yang dirasakan selama ini tidak cepat, kurangnya sarana prasarana yang dimiliki seperti masih ada sebagian peralatan kerja yang rusak, komputer yang tersedia terbatas maupun kurang nyamannya kapasitas ruang tunnggu bagi masyarakat,Dalam pengamatan yang dilakukan terkait dengan masalah kualitas layanan, peneliti menjumpai seorang pengunjung yang hendak membuat sporadik tanah harus menunggu pegawai yang biasa membuatkan sporadik tersebut semetara pegawai bersangkutan ada keperluan diluar kantor. Selain itu peneliti juga menjumpai pengunjung yang ingin menayakan informasi hendak menanyakan informasi mengenai perpindahan domisili namun pengunjung merasa kesulitan memahami pemberian informasi dari pegawai Kelurahan Batu Piring yang kurang jelas sehingga masyarakat menganggap kualitas pelayanan yang diberikan masih kurang optimal hal ini tercermin dari masih adanya pegawai yang lambat dalam bekerja, masih terlihatnya para pegawai kurang ramah dalam memberikan pelayanan kepada masyarakat dan juga masih kurang nyamannya fasilitas yang dimiliki oleh pihak Kelurahan membuat masyarakat kurang puas dalam berurusan di kantor Kelurahan. Dilihat dari data indeks kepuasan masyarakat (IKM) pada Kelurahan Batu Piring Kecamatan Paringin Selatan Kabupaten Balangan dan nilai standar IKM tersebut terlihat data pada periode tahun 2020 diketahui masih terdapat beberapa item pelayanan yang diberikan oleh pihak Kelurahan, masyarakat merasa masih kurang puas terhadap pelayanan yang diberikan seperti item waktu pelayanan yang biasa terkesan lambat, kompetensi pegawai, penanganan pengaduan, saran dan masukan serta sarana pelayanan.Berdasarkan data dan penjelasan tersebut penulis tertarik untuk mengadakan penelitian dengan judul penelitian "Pengaruh Kemampuan Pegawai, Sarana Layanan Terhadap Kualitas Layanan Dan Kepuasan Masyarakat Pada Kelurahan Batu Piring Kecamatan Paringin Selatan Kabupaten Balangan”.

\subsection{Rumusan Masalah}

Adapun yang menjadi perumusan masalah dalam peneltian ini adalah sebagai berikut:

1. Apakah kemampuan pegawai berpengaruh signifikan terhadap kualitas layanan pada Kelurahan Batu Piring Kecamatan Paringin Selatan Kabupaten Balangan?

2. Apakah sarana layanan berpengaruh signifikan terhadap kualitas layanan pada Kelurahan Batu Piring Kecamatan Paringin Selatan Kabupaten Balangan?

3. Apakah kemampuan pegawai berpengaruh signifikan terhadap kepuasan masyarakat pada Kelurahan Batu Piring Kecamatan Paringin Selatan Kabupaten Balangan?

4. Apakah sarana layanan berpengaruh signifikan terhadap kepuasan masyarakat pada Kelurahan Batu Piring Kecamatan Paringin Selatan Kabupaten Balangan?

5. Apakah kualitas layanan berpengaruh signifikan terhadap kepuasan masyarakat pada Kelurahan Batu Piring Kecamatan Paringin Selatan Kabupaten Balangan?

\subsection{Tujuan Penelitian}


Tujuan penelitian yang ingin dicapai dalam penelitian ini adalah sebagai berikut:

1. Untuk mengetahui dan menganalisis pengaruh kemampuan pegawai terhadap kualitas layanan pada Kelurahan Batu Piring Kecamatan Paringin Selatan Kabupaten Balangan.

2. Untuk mengetahui dan menganalisis pengaruh sarana layanan terhadap kualitas layanan pada Kelurahan Batu Piring Kecamatan Paringin Selatan Kabupaten Balangan.

3. Untuk mengetahui dan menganalisis pengaruh kemampuan pegawai terhadap kepuasan masyarakat pada Kelurahan Batu Piring Kecamatan Paringin Selatan Kabupaten Balangan.

4. Untuk mengetahui dan menganalisis pengaruh sarana layanan terhadap kepuasan masyarakat pada Kelurahan Batu Piring Kecamatan Paringin Selatan Kabupaten Balangan.

5. Untuk mengetahui dan menganalisis pengaruh kualitas layanan berpengaruh signifikan terhadap kepuasan masyarakat pada Kelurahan Batu Piring Kecamatan Paringin Selatan Kabupaten Balangan.

\section{BAB II TINJAUAN PUSTAKA \\ 2.1.Landasan Teori \\ 2.1.1. Manajemen Sumber Daya Manusia}

Menurut Sugeng (2015:5), mendefinisikan manajemen sebagai seni menyelesaikan pekerjaan melalui orang lain. Definisi ini berarti bahwa seorang manajer bertugas mengatur dan mengarahkan orang lain untuk mencapai tujuan organisasi.Menurut Abdurrachman (2013:9) mendefinisikan akan manajemen sebagai sebuah proses perencanaan, pengorganisasian, pengkoordinasian, dan pengontrolan sumber daya untuk mencapai sasaran (goals) secara efektif dan efesien.Menurut Handoko (2012:7) berpendapat bahwa pengertian manajemen merupakan keahlian untuk menggerakan orang agar melakukan sesuatu.Menurut Widya (2014:5), mengatakan bahwa manajemen merupakan proses yang khas yang terdiri dari tindakan-tindakan

perencanaan, pengorganisasian, menggerkan dan pengawasan yang dialkukan untuk menentukan serta mencapai sasaran-sasaran yang telah ditetapkan melalui pemanfaatan sumber daya manusia serta sumber-sumber lain.

Menurut Handoko (2012:13) menjelaskan dari fungsi manajemen yang paling mendasar yaitu sebagai berikut:

1. Perencanaan (planning) mencakup hal-hal pemilihan/penetaan tujuan organisasi dan penetuan strategi, kebijakan, proyeksi, program, metode, sistem, anggaran, dan standar yang dibutuhkan untuk mencapai tujuan.

2. Pengorganisasian (organizing) merupakan proses penyusunan struktur organisasi yang sesuai dengan tujuan, sumber daya organisasi, dan lingkungan tempat organisasi berada. Pengorganisasian bertujuan membagi suatu kegiatan yang besar menjadi kegiatan-kegiatan yang lebih kecil.

3. Penyusunan Personalia (staffing) merupakan penarikan, pelatihan, dan pengembangan serta penempatan dan pemberian orientasi pada karyawan dalam lingkungan kerja yang menguntungkan dan produktif.

4. Pengarahan (leading/directing) adalah membuat karyawan melakukan apa yang diinginkan dan harus dilakukan. Fungsi yang melibatkan kualitas, gaya, dan kekuasaan pemimpin. Kegiatan kepemimpinan misalnya komunikasi, motivasi, dan disiplin perlu diintensifkan oleh atasan.

5. Pengawasan (controlling) merupakan tindakan seorang manajer untuk menilai dan mengendalikan jalannya suatu kegiatan demi tercapainya tujuan yang telah ditetapkan. Dengan demikian, tujuan pengawasan adalah memperbaiki kesalahan, penyimpangan, penyelewengan dan kegiatan lainnya yang tidak sesuai dengan rencana.

\subsubsection{Kemampuan}

Rivai (2012:217) menjelaskan kemampuan berhubungan erat dengan kemampuan fisik dan mental yang dimiliki orang dalam melaksanakan pekerjaan. Kemampuan karyawan rendah akan menggunakan waktu dan usaha lebih besar dari pada karyawan yang berkemampuan tinggi untuk menyelesaikan suatu pekerjaan. Setiap jenis pekerjaan menurut pengetahuan, keterampilan dan sikap tertentu agar dapat melaksanakan pekerjaan dengan baik.Nova, (2013:7) menerangkan akan kemampuan memiliki komponen-komponen antara lain, pengetahuan, 
keahlian, dan perilaku, dengan demikian secara umum kompotensi dapat diartikan sebagai tingkat keterampilan pengetahuan dan tingkah laku yang dimiliki oleh seseorang/ individu dalam melaksanakan tugas yang dibebankan padanya dalam suatu unit organisasi yang juga bisa berarti kemampuan seseorang untuk menunjukkan hasil kerja sesuai dengan standar yang sudah ditentukan atau yang diperlukan.Muzzakir. (2013:77) kemampuan adalah aktivitas seseorang untuk menghasilkan pada tingkat kepuasan ditempat kerja, termasuk diantaranya kemampuan seseorang untuk mentransfer dan mengaplikasikan keterampilan dan pengatahuan tersebut dalam situasi yang baru dan meningkatkan manfaat yang disepakati. Selain itu kemampuan juga menunjukkan karakteristik pengetahuan dan keterampilan yang dimiliki atau dibutuhkan oleh setiap individu untuk meningkatkan mereka untuk melakukan tugas dan tanggung jawab serta kepuasan dalam bekerja, sehingga mereka secara efektif dan meningkatkan standar kualitas profesional dalam pekerjaan mereka. Winardi (2010:88) kemampuan kerja secara umum diartikan sebagai kecakapan, keterampilan, kemampuan. Kata dasarnya sendiri yaitu kompeten, tentu saja berarti cakap, mampu, atau terampil. Pada konteks manajemen SDM istilah kompetensi mengacu kepada atribut /karakteristik seseorang yang membuatnya berhasil dalam pekerjaannya. Selain itu menyatakan bahwa perubahan kemampuan, keterampilan, dan sikap yang positif merupakan salah satu ukuran keberhasilan peserta pengembangan organisasi. Susilo, (2013:137) menjelaskan akan definisi dari kemampuan adalah suatu kapasitas individu untuk mengerjakan berbagai tugas dalam suatu pekerjaan. Sedangkan kemampuan kerja meliputi kecerdasan, keperibadian, pengalaman, pelatihan, perhatian/ keterkaitan, pendidikan dan daya tarik. Handoko, (2012:83-84) metode latihan yang dapat digunakan untuk meningkatkan kemampuan kerja, yaitu :

$a$. On the job training merupakan metode latihan yang paling banyak dipergunakan, sistem ini terutama memberikan tugas kepada atasan langsung dari karyawan yang baru dilatih, untuk melatih mereka.

b. Vestibule school, merupakan bentuk latihan di mana pelatihannya bukanlah para atasan langsung, tetapi pelatih-pelatih khusus. Atau dalam pelatihan ini bukan dilaksanakan oleh atasan tetapi dilakukan oleh pelatih-pelatih khusus.

c. Apprenticeship, merupakan proses belajar dari seseorang atau beberapa orang yang lebih berpengalaman.

$d$. Kursus khusus, merupakan pelatihan yang dilakukan sesuai dengan minat dari para karyawan dalam bidang pengetahuan tertentu, seperti kursus manajemen dan lain-lain.

Menurut Mathis (2006) dalam Wibowo (2013:137) menjelaskan faktor utama yang mempengaruhi kemampuan seseorang dalam bekerja, yaitu keyakinan dan nilai-nilai, keterampilan, pengalaman, karakteristik pribadi, motivasi dan isu emosional

\subsubsection{Sarana Layanan}

Soelarso (2014:109) menjelaskan sarana adalah segala sesuatu yang dipakai sebagai alat untuk mecapai makna dan tujuan. Sebagai contoh sarana kerja diartikan sebagai alat untuk mencapai tujuan pekerjaan, misalnya komputer PC, laptop, meja, kursi dan lain-lain. Sedangkan prasarana adalah segala sesuatu yang menunjang utama terhadap terselenggaranya suatu proses kerja serta pelayanan, misalnya gedung, ruang kerja dan lain-lain.Menurut Komariah (2012:198) menjelaskan akan aktivitas para pegawai, di dalam kantor kelangsungannya pekerjaannya akan banyak dipengaruhi oleh kondisi dan situasi fisik, lingkungan dan fasilitas kerja yang tersedia. Oleh sebab itulah lingkungan fisik kantor berupa sarana dan prasarana harus dapat memenuhi dan mendukung interaksi yang terjadi, sehingga harmonisasi kehidupan kerja dapat berlangsung dengan baik dari permulaan masa kerja sampai akhir masa kerja. Menurut Moenir (2012:119) pengertian sarana prasarana adalah segala jenis peralatan, perlengkapan kerja dan fasilitas yang berfungsi sebagai alat utama atau pembantu dalam pelaksanaan kerja dan juga dalam rangka kepentingan yang sedang berhubungan dengan organisasi kerja serta pelayanan. Murniaty (2013:111) menjelaskan sarana adalah peralatan dan perlengkapan yang secara langsung dipergunakan dan menunjang proses kerja, seperti gedung, ruang kerja, meja, kursi, serta alat-alat dan media elektronik. Adapun yang dimaksud dengan prasarana adalah fasilitas yang secara tidak langsung menunjang jalannya proses 
layanan kerja, seperti halaman, kantin, taman, lapangan upacaran, lapangan olahraga. Mulyasa, (2015:49) Sarana dan prasarana/fasilitas kerja adalah perlengkapan yang diperlukan untuk menyelenggarakan pekerjaan yang dapat dipindah-pindah. Prasarana adalah fasilitas dasar yang diperlukan untuk menjalankan fungsi satuan kerja.Dalam konteks pekerjaan, pengertian mutu mencakup input, proses, dan output kerja. Input kerja adalah segala sesuatu yang harus tersedia karena dibutuhkan untuk berlangsungnya proses. Proses pekerjaan merupakan berubahnya sesuatu menjadi sesuatu yang lain dengan mengintegrasikan input pekerjaan sehingga mampu menciptakan situasi pekerjaan yang menyenangkan, mampu mendorong motivasi dan minat kerja, dan benar-benar mampu memberdayakan pegawai. Output pekerjaan merupakan kinerja pegawai yang dapat diukur dari kualitasnya, efektivitasnya, produktivitasnya, efisiensinya, inovasinya, dan moral kerjanya serta menciptakan akurasi pelayanan yang baik.Sumarsono (2012:88) menjelaskan sarana prasarana kerja adalah segala sesuatu yang berkaitan dengan proses kerja serta menunjangterhadap kegiatan pelayanan, meliputi : gedung tempat kerja, perkantoran, ruang kerja, tranportasi, peralatan dan dan perlengkapan kantor, makin lengkap fasilitas kantor, maka akan semakin lancar dan tertib dalam proses pekerjaan.Menurut Moenir (2012:121) menjelaskan fungsi utama dari sarana layanan, yaitu sebagai berikut:

1. Mempercepat proses pelaksanaan pekerjaan sehingga mampu menghemat waktu

2. Meningkatkan produktivitas baik barang maupun jasa

3. Hasil kerja lebih berkualitas serta terjamin

4. Lebih sederhana atau memudahkan dalam gerak para pengguna atau pelaku

5. Ketetapan susunan stabilitas pekerja lebih terjamin

6. Menimbulkan rasa kenyamanan bagi orangorang yang berkepentingan

7. Menimbulkan rasa puas pada roang-orang yang berkepentingan yang mempergunakannya.

Komariah (2012:105) menjelaskan fungsi dari sarana dan prasarana layanan kerja adalah sebagai berikut:

a. Menciptakan kenyamanan kerja b. Menciptakan kepuasan kerja

c. Mempercepat proses kerja

d. Memudahkan proses kerja

e. Meningkatkan hasil kerja atau produktivitas kerja

f. Hasil kerja lebih berkualitas

\subsubsection{Kualitas Layanan}

Pelayanan yang baik memungkinkan sebuah perusahaan memperkuat kesetiaan pelanggan dan meningkatkan pangsa pasar (market share), karena itu pelayanan yang baik menjadi penting dalam operasi perusahaan. Selain itu service adalah kegiatan yang dapat diidentifikasikan dan tidak berwujud dan merupakan tujuan penting dari suatu rencana transaksi, guna memberikan kepuasan kepada konsumen. Amir, (2013:27) layanan hakikatnya adalah serangkaian kegiatan, karena ia merupakan proses. Sebagai proses, layanan berlangsung secara rutin dan berkesinambungan meliputi seluruh kehidupan organisasi dalam masyarakat.Susilo (2013:36), mendefinisikan pelayanan adalah "suatu tindakan yangdilakukan untuk memenuhi kebutuhan orang lain yang tingkat kepuasan hanyadapat dirasakan oleh yang melayani maupun yang dilayani.Menurut Makmun, (2012:90) mengemukakan pelayanan atau service adalah setiap kegiatan atau manfaat yang ditawarkan oleh suatu pihak kepada pihak lain dan pada dasarnya tidak berwujud dan tidak pula berakibat kepemilikian sesuatu dan produksinya dapat atau tidak dapat dikaitkan dengan suatu produk fisik. Menurut Siregar (2013:152) layanan adalah kegiatan pemberian jasa dari satu pihak kepada pihak lainnya. Pelayanan yang baik adalah pelayanan yang dilakukan secara ramah tamah, adil, cepat, tepat, dan etika yang baik sehingga memenuhi kebutuhan dan kepuasan bagi yang menerimanya.Menurut pendapat Rasyid, (2013:88) pelayanan dapat diartikan sebagai pemberian layanan (melayani) keperluan orang atau masyarakat yang mempunyai kepentingan pada organisasi itu sesuai dengan aturan pokok dan tata cara yang telah ditetapkan. Sebagaimana telah dikemukakan terdahulu bahwa pemerintah pada hakekatnya adalah pelayan masyarakat. Ia tidaklah diadakan untuk melayani dirinya sendiri tetapi untuk melayani masyarakat serta menciptakan kondisi yang memungkinkan setiap anggota masyarakat mengembangkan kemampuan dan kreativitas demi mencapai 
tujuan bersama. Selain itu juga Makmun (2012:75) menjelaskan pelayanan adalah proses pemenuhan kebutuhan melalui aktivitas orang lain secara langsung.Eko, (2011:148) menjelaskan layanan adalah sebagai seberapa jauh perbedaan antara kenyataan dan harapan pelanggan atas layanan yang mereka terima/peroleh.Sami, (2010:105) pelayanan adalah aktivitas atau hasil yang dapat ditawarkan oleh sebuah lembaga kepada pihak lain yang biasanya tidak kasat mata dan hasilnya tidak dapat dimiliki oleh pihak lain.Hadipranata (2010:132) pelayanan adalah aktivitas tambahan di luar tigas pokok yang diberikan kepada konsumen atau pelanggan, nasabah dan sebagainya serta dirasakan baik sebagai penghargaan maupun penghormatan.Hanif, (2014:35) menjelaskan kualitas layanan adalah upaya pemenuhan kebutuhan yang dibarengi dengan keinginan konsumen serta ketepatan cara penyampaian agar dapat memenuhi harapan dan kepuasan pelanggan tersebut.Hendrik (2010:27) menjelaskan kualita layanan adalah untuk meningkatkan proses operasional, mengindentifikasi masalah dengan cepat dan sistematis dengan membangun kinerja pelayanan yang akurat dan dapat di andalkan guna meningkatkan kepuasan dan hasil kerja yang optimal.

Darmawan (2011:46) menjelaskan kualitas pelayanan yang dirasakan kosumen, terdapat beberapa faktor indikator, yaitu:

a. Faktor berwujud, yaitu kualitas pelayanan secara langsung dalam bentuk fisik seperti kantor, perlengkapan, pelaratan dan alat penunjang lain yang membantu memperlancari proses pelayanan.

b. Faktor Keandalanadalah kemampuan dan keandalan untuk menyediakan pelayana yang terpercaya seperti kecermatan petugas, standar pelayanan kemampuan petugas dan keahlian petugas dalam bekerja.

c. Faktor Ketanggapanadalah kesanggupan untuk membantu dan menyediakan pelayanan secara cepat datepat, seperti merespon pelanggan, petugas melakukan pelayanan cepat, petugas melakukan pelayanan tepat dan cermat.

d. Faktor Jaminanadalah kemampuan dan keramahan serta sopan santun pegawai dalam membeirkan kepercayaan kepada konsumen, seperti memberikan jaminan tepat waktu, jaminan biaya dalam pelayanan, jaminan legalitas dan kepastian biayan pelayanan

e. Faktor Empati adalah sikap tegas tetapi penuh perhatian dari pegawai terhadap konsumen, seperti mendahulukan kepentingan pelanggan, melayani sikap ramah, melayani dengan sikap sopan santun, tidak deskriminatif dan menghargai pelanggan

Keputusan Menteri Pemberdayaan Aparatur Negara Pemerintah Nomor 96 Tahun 2012 pelaksanaan terhadap Kepmen Nomor KEP25/M.PAN/2/2009 tanggal 24 pebruari 2009 terdapat 14 indikator pelayanan sebagai berikut:

1. Prosedur pelayanan yaitu kemudahan tahap pelayanan yang diberikan kepada masyarakat.

2. Persyaratan pelayanan yaitu persyaratan teknis dan administratif yang diperlukan untuk mendapatkan pelayana sesuai dengan jenis pelayanannya.

3. Kejelasan petugas pelayanan yaitu keberadaan dan kepastian petugas yang memberikan pelayanan.

4. Kedisiplinan petugas pelayanan yaitu kesungguhan petugas dalam memberikan pelayanan terutama konsisten waktu kerja sesuai ketentuan yang berlaku.

5. Tanggungjawab petugas pelayanan yaitu kejelasan wewenang dan tanggung jawab dalam penyelenggaraan dan penyelesaian pelayanan.

6. Kemampuan petugas pelayanan yaitu tiingkat keahlian dan keterampilan yang dimiliki petugas dalam memberikan pelayanan.

7. Kecepatan pelayanan yaitu Target waktu pelayanan dapat diselesaikan dalam waktu yang ditentukan.

8. Keadilan dalam mendapatkan pelayanan yaitu pelaksanaan pelayanan dengan tidak membedakan golongan/stattus masyarakat yang dilayani.

9. Kesopanan dan keramahan petugas yaitu bentuk sikap dan perilaku petugas yang baik sopan dan ramah dalam memberikan pelayanan.

10. Kewajaran biaya pelayanan yaitu Keterjangkauan masyarakat terhadap besarnya biaya pelayanan. 
11. Kepastian biaya pelayanan yaitu kesesuaian antara biaya yang dibayar dengan biaya yang ditetapkan.

12. Kepastian jadwal pelayanan yaitu yaitu disiplin terhadap pelaksanaan waktu pelayanan sesuai dengan ketentuan.

13. Kenyamanan lingkungan yaitu menyangkut kondisi sarana dan prasaran dapat diberikan dengan nyaman kepada penerima layanan.

14. Keamanan pelayanan yaitu terjaminnya tingkat keamanan lingkungan unit penyelnggaraan pelayanan.

\subsubsection{Kepuasan Masyarakat}

Pelayanan masyarakat harus ditangani secara profesional, karena dengan pelayanan yang baik dan profesional, akan mencerminkan aparat pemerintah atau pegawai bekerja sesuai dengan aturan yang telah ditetapkan. Peraturan Menteri Pendayagunaan Aparatur Negara Dan Reformasi Birokrasi Republik Indonesia Nomor 16 Tahun 2014 Tentang Pedoman Survei Kepuasan Masyarakat terhadap Penyelenggaraan Pelayanan Publik Dengan Rahmat Tuhan Yang Maha Esa Menteri Pendayagunaan Aparatur Negara Dan Reformasi Birokrasi Pasal 1 Survei Kepuasan Masyarakat adalah pengukuran secara komprehensif kegiatan tentang tingkat kepuasan masyarakat yang diperoleh dari hasil pengukuran atas pendapat masyarakat. Survei Kepuasan Masyarakatatau SKM harus dilaksanakan oleh penyelenggara pelayanan publik secara berkelanjutan sebagai dasar peningkatan kualitas dan inovasi pelayanan publik dengan jangka waktu minimal 1 tahun sekali. Hasil survei tersebut kemudian dipublikasikan kepada masyarakat melalui media massa, website, dan media sosial baik dalam bentuk skoring/angka absolut, atau dapat pula disajikan dalam bentuk kualitatif (baik atau buruk).Menurut Sutrisno (2012:113) kepuasan adalah sebagai salah satu bentuk perasaan senang/kecewa seseorang yang dialami setelah membandingkan antara persepsi kinerja atau hasil suatu produk dengan harapanharapannya atau sesuai dengan yang diinginkan.Menurut Dewantara (2011:52) menjelaskan kepuasan adalah tingkat perasaan seseorang setelah membandingkan kinerja (atau hasil) yang ia rasakan dibandingkan dengan harapannya.Menurut Supiani (2010:24) menjelaskan bahwa kepuasan adalah tingkat perasaan seseorang setelah membandingkan kinerja (atau hasil) yang ia rasakan dibandingkan dengan harapannya atau terpenuhinya kebutuhan sesuai dengan permintaan pelanggan.

Unsur Indeks Kepuasan Masyarakat berdasarkan prinsip pelayanan sebagaimana telah ditetapkan dalam Keputusan Menteri Pendayagunaan Aparatur Negara Nomor No. 96/2012, yang kemudian dikembangkan menjadi 14 unsur yang relevan, valid, dan reliable, sebagai unsur minimal yang harus ada untuk dasar pengukuran indeks kepuasan masyarakat adalah:

1. Prosedur pelayanan yaitu kemudahan tahapan pelayanan yang diberikan kepada masyarakat dilihat dari sisi kesederhanaan alur pelayanan.

2. Persyaratan pelayanan yaitu persyaratan teknis dan administratif yang diperlukan untuk mendapatkan pelayanan sesuai dengan jenis pelayanannya

3. Kejelasan petugas pelayanan yaitu keberadaan dan kepastian petugas yang memberikan pelayanan (nama, jabatan serta kewenangan dan tanggung jawabnya)

4. Kedisiplinan petugas pelayanan yaitu kesungguhan petugas dalam memberikan pelayanan terutama terhadap konsistensi waktu kerja sesuai ketentuan yang berlaku.

5. Tanggungjawab petugas pelayanan yaitu kejelasan wewenang dan tanggung jawab petugas dalam penyelenggaraan dan penyelesaian pelayanan

6. Kemampuan petugas pelayanan yaitu tingkat keahlian dan keterampilan yang dimiliki petugas dalam memberikan/ menyelesaikan pelayanan kepada mayarakat.

7. Kecepatan pelayanan yaitu target waktu pelayanan dapat diselesaikan dalam waktu yang telah ditentukan oleh unit penyelenggara pelayanan;

8. Keadilan mendapatkan pelayanan yaitu pelaksanaan pelayanan dengan tidak membedakan golongan/status masyarakat yang dilayani

9. Kesopanan dan keramahan petugas yaitu sikap dan perilaku petugas dalam memberikan pelayanan kepada masyarakat secara sopan dan ramah serta saling menghargai dan menghormati.

10. Kewajaran biaya pelayanan yaitu keterjangkauan masyarakat terhadap 
besarnya biaya yang ditetapkan oleh unit pelayanan

11. Kepastian biaya pelayanan yaitu kesesuaian antara biaya yang dibayarkan dengan biaya yang telah ditetapkan

12. Kepastian jadwal pelayanan yaitu pelaksanaan waktu pelayanan, sesuai dengan ketentuan yang telah ditetapkan.

13. Kenyamanan lingkungan yaitu kondisi sarana dan prasarana pelayanan yang bersih, rapi, dan teratur sehingga dapat memberikan rasa nyaman kepada penerima pelayanan.

14. Keamanan pelayanan yaitu terjaminnya tingkat keamanan lingkungan unit penyelenggara pelayanan ataupun sarana yang digunakan, sehingga masyarakat merasa tenang untuk mendapatkan pelayanan terhadap resiko-resiko yang diakibatkan dari pelaksanaan pelayanan.

Peraturan Menteri Pendayagunaan Aparatur Negara dan Reformasi Birokrasi Nomor 14 Tahun 2017 tentang Pedoman Penyusunan Survei Kepuasan Masyarakat menjelaskan unsur-unsur yang menjadi fokus dalam pelaksanaan Survei Kepuasan Masyarakat terdiri dari 9 unsur yang terdiri dari :

1. Persyaratan adalah syarat yang harus dipenuhi dalam pengurusan suatu jenis pelayanan, baik persyaratan teknis maupun administrative.

2. Sistem, mekanisme dan prosedur adalah tata cara pelayanan yang dilakukan bagi pemberi dan penerima pelayanan termasuk pengaduan.

3. Waktu penyelesaian adalah jangka waktu yang diperlukan untuk menyelesaikan seluruh proses pelayanan dari setiap jenis pelayanan.

4. Biaya/Tarif adalah suatu bentuk beban atau ongkos yang dikenakan kepada penerima layanan dalam mengurus dan atau memperoleh pelayanan dari penyelenggara yang besarnya ditetapkan Berdasarkan kesepakatan antara penyelenggara dan masyarakat.

5. Produk Spesifikasi Jenis Pelayanan adalah hasil pelayanan yang diberikan dan diterima sesuai dengan ketentuan yang ditetapkan. Produk pelayanan ini merupakan hasil dari setiap spesifikasi jenis pelayanan.

6. Kompetensi Pelaksana adalah kemampuan yang harus dimiliki oleh pelaksana meliputi pengetahuan keahlian keterampilan dan pengalaman.
7. Perilaku Pelaksana adalah sikap petugas memberikan pelayanan

8. Penanganan pengaduan, saran dan masukan adalah suatu aktivitas atau tata cara pelaksanaan penanganan pengaduan dan tindak lanjut.

9. Sarana adalah segala sesuatu yang dapat dipakai sebagai alat dalam mencapai maksud dan tujuan. Prasarana adalah segala sesuatu yang merupakan penunjang utama terselenggaranya suatu proses (usaha, pembangunan, proyek). Sarana yang digunakan untuk benda yang bergerak (komputer,mesin) dan prasarana untuk benda yang tidak bergerak (gedung).

\section{BAB III}

\section{KERANGKA KONSEPTUAL DAN HIPOTESIS}

\subsection{Kerangka Konseptual}

Kerangka berfikir merupakan model konseptual tentang bagaimana teori hubungan dengan berbagai faktor yang diidentifikasi sebagai masalah yang penting. Kerangka berfikir yang baik akan menjelaskan secara teoritis pertautan antar variabel yang akan diteliti, yang selanjutnya dirumuskan dalam bentuk paradigma penelitian dan setiap menyusun paradigma penelitian harus didasarkan pada kerangka berpikir. Menurut Sugiyono (2012:27). Kerangka konseptual dalam penelitian ini yang termasuk dalam variable bebas adalah kemampuan pegawai (X1) dan sarana layanan (X2) untuk variabel perantara (intervening) yaitu kualitas layanan( $\mathrm{Z}$ ) terhadap variabel terikat yaitu kepuasan masyarakar(Y). Pada penelitian ini bermaksud untuk menjelaskan pengaruh antar variabel melalui pengujian hipotesis dan sekaligus melakukan eksplanasi terhadap beberapa variabel, maka sifat penelitian ini adalah penelitian eksplanatori (explanatory research).

Kerangka konseptual dalam penelitian ini dapat di gambarkan sebagai berikut:

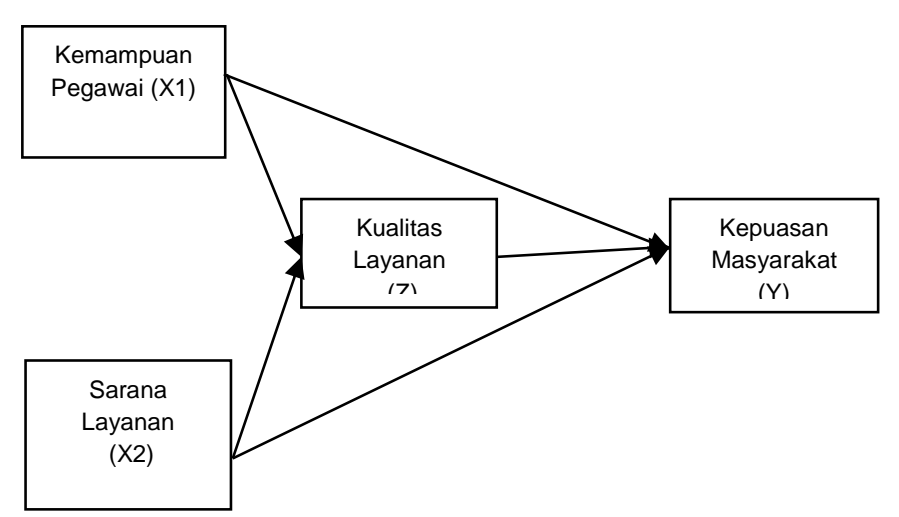




\section{Gambar 3.1: Kerangka Konseptual}

\subsection{Hipotesis Penelitian}

1. Kemampuan pegawai berpengaruh signifikan terhadap kualitas layanan pada Kelurahan Batu Piring Kecamatan Paringin Selatan Kabupaten Balangan.

2. Sarana layanan berpengaruh signifikan terhadap kualitas layanan pada Kelurahan Batu Piring Kecamatan Paringin Selatan Kabupaten Balangan.

3. Kemampuan pegawai berpengaruh signifikan terhadap kepuasan masyarakat pada Kelurahan Batu Piring Kecamatan Paringin Selatan Kabupaten Balangan.

4. Sarana layanan berpengaruh signifikan terhadap kepuasan masyarakat pada Kelurahan Batu Piring Kecamatan Paringin Selatan Kabupaten Balangan.

5. Kualitas layanan berpengaruh signifikan terhadap kepuasan masyarakat pada Kelurahan Batu Piring Kecamatan Paringin Selatan Kabupaten Balangan.

\section{BAB V}

\section{ANALISIS HASIL PENELITIAN DAN PEMBAHASAN}

5.1. Analisis Hasil Penelitian

\subsubsection{Pengujian Instrumen}

\section{Uji Validitas}

Adapun uji validitas atas instrument didalam penelitian ini dapat disampaikan, yaitu:

\section{Tabel 5.10}

Uji Validitas Instrumen

Kemampuan Pegawai $\left(\mathbf{X}_{1}\right)$

\begin{tabular}{|c|c|c|}
\hline Variable & $\begin{array}{c}\mathrm{r}_{\text {hitung }} \\
\text { (Lihat } \\
\text { Lampiran 3) }\end{array}$ & $\begin{array}{c}\mathrm{r}_{\text {tabel }} \\
\text { (Lihat } \\
\text { Lampiran 6) }\end{array}$ \\
\hline $\mathrm{X} 1.1$ & $0,635(* *)$ & 0,204 \\
$\mathrm{X} 1.2$ & $0,730(* *)$ & 0,204 \\
$\mathrm{X} 1.3$ & $0,794(* *)$ & 0,204 \\
$\mathrm{X} 1.4$ & $0,804(* *)$ & 0,204 \\
$\mathrm{X} 1.5$ & $0,679(* *)$ & 0,204 \\
$\mathrm{X} 1.6$ & $0,605(* *)$ & 0,204 \\
\hline
\end{tabular}

Sumber : data primer diolah

Hasil uji validitas variabel independent yaitu kemampuan pegawai $\left(\mathrm{X}_{1}\right)$ disimpulkan bahwa semua instrumen pertanyaan tersebut valid ini terbukti dengan membandingkan ( $\mathrm{r}_{\text {hitung }}$ ) dengan $\mathrm{r}_{\text {tabel }}$ pada $\alpha 0,05$ yang mana diambil keputusan jika nilai $r_{\text {hitung }}$ positip dan $r_{\text {hitung }}>r_{\text {tabel }} l$, maka instrumen pertanyaan tersebut valid.

Tabel 5.11

Uji Validitas Instrumen Sarana Layanan $\left(\mathbf{X}_{2}\right)$

\begin{tabular}{|c|c|c|}
\hline Variable & $\begin{array}{c}\mathrm{r}_{\text {hitung }} \\
\text { (Lihat } \\
\text { Lampiran 3) }\end{array}$ & $\begin{array}{c}\mathrm{r}_{\text {tabel }} \\
\text { (Lihat } \\
\text { Lampiran 6) }\end{array}$ \\
\hline X2.1 & $0,675(* *)$ & 0,204 \\
X2.2 & $0,762(* *)$ & 0,204 \\
X2.3 & $0,796(* *)$ & 0,204 \\
X2.4 & $0,809(* *)$ & 0,204 \\
X2.5 & $0,770(* *)$ & 0,204 \\
X2.6 & $0,553(* *)$ & 0,204 \\
\hline
\end{tabular}

Sumber :data primer diolah

Hasil uji validitas variabel dependent yakni sarana layanan $\left(\mathrm{X}_{2}\right)$ dapat disimpulkan bahwa semua instrumen pertanyaan tersebut valid ini terbukti dengan membandingkan ( $\mathrm{r}_{\text {hitung }}$ ) dengan $\mathrm{r}_{\text {tabel }}$ pada $\alpha$ 0,05 yang mana diambil keputusan jika nilai $r_{\text {hitung }}$ positip dan $r_{\text {hitung }}>r_{\text {tabel }}$, maka instrumen pertanyaan valid.

Tabel 5.12

Uji Validitas Instrumen Kualitas Layanan (Z)

\begin{tabular}{|c|c|c|}
\hline Variable & $\begin{array}{c}\mathrm{r}_{\text {hitung }} \\
\text { (Lihat Lampiran } \\
\text { 3) }\end{array}$ & $\begin{array}{c}\mathrm{r}_{\text {tabel }} \\
\text { (Lihat } \\
\text { Lampiran 6) }\end{array}$ \\
\hline $\mathrm{Z} 1.1$ & $0,745\left(^{* *}\right)$ & 0,204 \\
$\mathrm{Z} 1.2$ & $0,758(* *)$ & 0,204 \\
$\mathrm{Z} 1.3$ & $0,843\left(^{* *}\right)$ & 0,204 \\
$\mathrm{Z} 1.4$ & $0,799\left(^{* *}\right)$ & 0,204 \\
$\mathrm{Z} 1.5$ & $0,764\left(^{* *}\right)$ & 0,204 \\
\hline
\end{tabular}

Sumber :data primer diolah

Hasil uji validitas variabel dependent yakni kualitas layanan $\left(\mathrm{X}_{3}\right)$ dapat disimpulkan bahwa semua instrumen pertanyaan tersebut valid ini terbukti dengan membandingkan ( $\mathrm{r}_{\text {hitung }}$ ) dengan $r_{\text {tabel }}$ pada $\alpha$ 0,05 yang mana diambil keputusan jika nilai $r_{\text {hitung }}$ positip dan $r_{\text {hitung }}>r_{\text {tabel }}$, maka instrumen pertanyaan tersebut valid.

Tabel 5.13

Uji Validitas Instrumen

Kepuasan Masyarakat (Y)

\begin{tabular}{|c|c|c|}
\hline Variable & $\begin{array}{c}\mathrm{r}_{\text {hitung }} \\
(\text { Lihat Lamp3) }\end{array}$ & $\begin{array}{c}\mathrm{r}_{\text {tabel }} \\
\text { (Lihat Lamp6) }\end{array}$ \\
\hline $\mathrm{Y} 1.1$ &, $456\left(^{* *}\right)$ & 0,276 \\
$\mathrm{Y} 1.2$ &, $593(* *)$ & 0,276 \\
\hline
\end{tabular}




\begin{tabular}{|l|l|l|}
\hline Y1.3 &, $703(* *)$ & 0,276 \\
Y1.4 &, $689(* *)$ & 0,276 \\
Y1.5 &, $577(* *)$ & 0,276 \\
Y1.6 &, $723(* *)$ & 0,276 \\
Y1.7 &, $735(* *)$ & 0,276 \\
Y1.8 &, $600(* *)$ & 0,276 \\
Y1.9 &, $442(* *)$ & 0,276 \\
\hline
\end{tabular}

Sumber :data primer diolah

Hasil uji validitas variabel dependent yakni kepuasan masyarakat(Y)dapat disimpulkan bahwa semua instrumen pertanyaan tersebut valid ini terbukti dengan membandingkan ( $r_{\text {hitung }}$ ) dengan $r_{\text {tabel }}$ pada $\alpha$ 0,05 yang mana diambil keputusan jika nilai $r_{\text {hitung }}$ positip dan $r_{\text {hitung }}>r_{\text {tabel, }}$, maka instrumen pertanyaan tersebut valid.

\section{Uji Reliabilitas}

Tabel 5.14

Hasil Uji Reliabilitas

\begin{tabular}{|l|c|c|}
\hline \multicolumn{1}{|c|}{ Variable } & $\begin{array}{c}\text { Cronbach's } \\
\text { Alpha } \\
\text { (Lamp 4) }\end{array}$ & $\begin{array}{c}\text { Data } \\
\text { Baku }\end{array}$ \\
\hline Kemampuan pegawai (X1) & 0,779 & 0,60 \\
Sarana layanan (X2) & 0,783 & 0,60 \\
Kualitas layanan (Z) & 0,802 & 0,60 \\
Kepuasan Masyarakat (Y) & 0,750 & 0,60 \\
\hline
\end{tabular}

Sumber: data primer diolah

melihat dari data pada tabel tersebut terlihat nilai Cronbach's Alpha lebih besar dibanding dengan dara baku, maka kesimpulannya hasil uji relibilitas dalam penelitian ini datanya reliabel.

\subsubsection{Uji Asumsi Klasik}

\section{Struktur I (Variabel X ke Z)}

a. Uji Multikolinieritas

Tabel 5.15

\section{Hasil Uji Multikolinieritas Struktur I}

\begin{tabular}{|l|c|c|}
\hline \multirow{2}{*}{ Variabel } & \multicolumn{2}{|c|}{ Collinierarity Statistic's } \\
\cline { 2 - 3 } & Tolerance & VIF \\
\hline $\begin{array}{l}\text { Kemampuan pegawai } \\
\text { (X1) }\end{array}$ & 0,990 & 1,004 \\
\hline Sarana layanan (X2) & 0,996 & 1,053 \\
\hline
\end{tabular}

\section{Sumber: Lampiran 5}

Hasil uji multikolinieritas nilai tolerance mendekati 1 dan nilai variance inflation factor (VIF) menunjukkan tidak ada satu pun variabel bebas memiliki nilai VIF lebih dari 10 . Disimpulkan bahwa hasil penelitian ini tidak ada gejala multikolinieritas antar variabel bebas dalam model regresi, berarti data normal.

\section{b. Uji Heteroskedastisitas}

Berikut hasil uji Heteroskedastisitas dalam penelitian ini, yaitu :

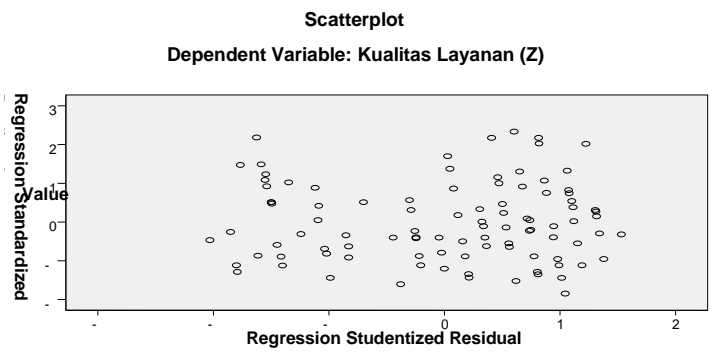

Grafik scatterplots di atas ini terlihat titik-titik menyebar secara acak serta tersebar baik di atas maupun di bawah angka 0 pada sumbu Z. Hal ini dapat disimpulkan bahwa tidak terjadi heteroskedastisitas pada model regresi, sehingga model regresi layak dipakai untuk memprediksi variabel terikat berdasarkan pengaruh variabel bebas, berarti data normal.

\section{c. Uji Normalitas}

Uji normalitas dilakukan untuk mengetahui apakah dalam model regresi variabel dependen dan variabel independen keduanya mempunyai distribusi normal atau tidak melalui analisis grafik. Adapun hasil dari uji normalitas ditampilkan pada gambar berikut:

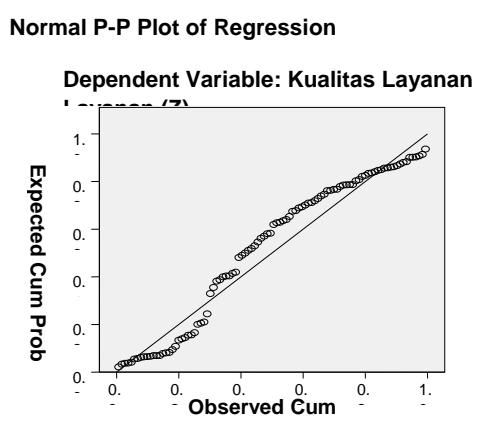

Berdasarkan gambar 5.3 grafik normal p-p plot yang menunjukkan bahwa grafik terlihat titik-titik menyebar disekitar garis diagonal, serta penyebarannya mengikuti arah garis diagonal. Kedua grafik ini menunjukkan bahwa model regresi layak dipakai untuk memprediksi kinerja berdasarkan masukan dari variabel independen kerja karena memenuhi uji asumsi normalitas, sehingga data dianggap normal.

\section{Struktur II (Variabel X, Z ke Y)}

\section{a. Uji Multikolinieritas Struktur II}

Berikut hasil uji multikolinieritas untuk struktur II, sebagai berikut : 
Tabel 5.16

Hasil Uji Multikolinieritas Struktur II

\begin{tabular}{|l|c|c|}
\hline \multirow{2}{*}{ Variabel } & \multicolumn{2}{|c|}{$\begin{array}{c}\text { Collinierarity } \\
\text { Statistic's }\end{array}$} \\
\cline { 2 - 3 } & Tolerance & VIF \\
\hline $\begin{array}{l}\text { Kemampuan pegawai } \\
\text { (X1) }\end{array}$ & 0,990 & 1,025 \\
\hline Sarana layanan (X2) & 0,993 & 1,099 \\
\hline Kualitas layanan (Z) & 0,997 & 1,113 \\
\hline
\end{tabular}

Sumber: Lampiran 5

Terlihat bahwa nilai tolerance mendekati 1 dan nilai variance inflation factor (VIF) di atas menunjukkan tidak ada satu pun variabel bebas yang memiliki nilai VIF lebih dari 10. Jadi dapat disimpulkan bahwa hasil penelitian ini tidak ada gejala multikolinieritas antar variabel bebas dalam model regresi.

\section{b. Uji HeteroskedastisitasStruktur II}

Berikut hasil uji heteroskedastisitas struktur II dalam penelitian ini adalah :

Scatterplot

Dependent Variable: Kepuasan Masyarakat (Y)

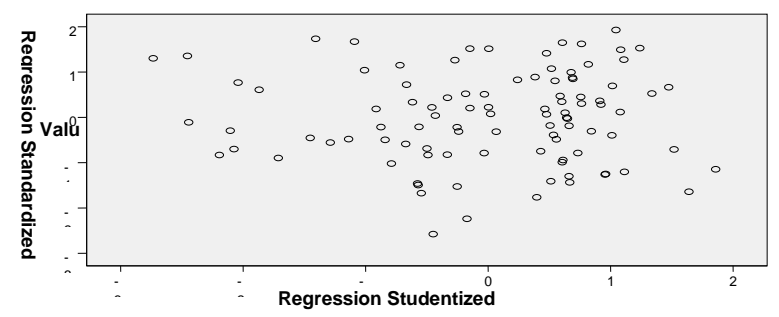

Gambar 5.4 : Scatterplot struktur I

Berdasarkan grafik scatterplots di atas ini terlihat titik-titik menyebar secara acak serta tersebar baik di atas maupun di bawah angka 0 pada sumbu Y. Hal ini dapat disimpulkan bahwa tidak terjadi heteroskedastisitas pada model regresi, sehingga model regresi layak dipakai untuk memprediksi variabel terikat berdasarkan pengaruh variabel bebas.

\section{c. Uji Normalitas}

Uji normalitas dilakukan untuk mengetahui apakah dalam model regresi variabel dependen dan variabel independen keduanya mempunyai distribusi normal atau tidak melalui analisis grafik. Uji normalitas ditampilkan pada gambar berikut:

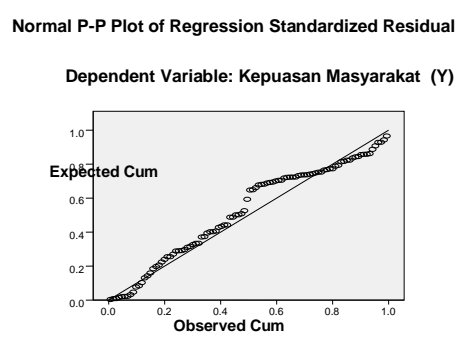

Gambar 5.5 Diagram Normal P-P Plot

Berdasarkan gambar 5.5 grafik normal $p$ - $p$ plot yang menunjukkan bahwa grafik terlihat titik-titik menyebar disekitar garis diagonal, serta penyebarannya mengikuti arah garis diagonal. Grafik ini menunjukkan bahwa model regresi layak dipakai untuk memprediksi kepuasan masyarakat berdasarkan masukan dari variabel independen dan variabel perantara karena memenuhi uji asumsi normalitas.

\subsubsection{Analisis Path dengan Metode Regresi Berganda}

\section{Hasil Regresi Struktur I}

Pengujian hipotesis dalam penelitian ini dilakukan dengan Analisis Regresi Berganda untuk menentukan kontribusi relatif tiap variabel bebas dalam menjelaskan pengaruhnya terhadap variabel terikat. Untuk menguji hal tersebut, perlu dilakukan uji hipotesis dengan menggunakan uji regresi berganda melalui program spss, berikut ini rekapitulasi hasil regresi berganda tersebut adalah

Tabel 5.17

Hasil Analisis Path dengan Metode Regresi BergandaUji Struktur ICoefficients(a)

\begin{tabular}{|c|c|c|c|c|c|c|c|}
\hline & \multicolumn{2}{|c|}{$\begin{array}{c}\text { Unstandardized } \\
\text { Coefficients }\end{array}$} & \multirow{2}{*}{$\begin{array}{c}\text { Standardized } \\
\text { Coefficients } \\
\text { Beta }\end{array}$} & \multirow[b]{2}{*}{$\mathrm{t}$} & \multirow[b]{2}{*}{ Sig. } & \multicolumn{2}{|c|}{$\begin{array}{c}\text { Collinearity } \\
\text { Statistics }\end{array}$} \\
\hline & B & $\begin{array}{l}\text { Std. } \\
\text { Error }\end{array}$ & & & & $\begin{array}{c}\text { Toleran } \\
\text { ce }\end{array}$ & VIF \\
\hline (Consta & 16,707 & 2,56 & & 6,52 &, 000 & & \\
\hline $\begin{array}{l}\text { nt) } \\
\text { Kemam }\end{array}$ & & 0 & & 6 & & & \\
\hline puan &, 723 & ,119 & ,720 & 6,07 &, 001 & ,990 & 1,004 \\
\hline $\begin{array}{l}\text { Pegawa } \\
\text { i (X1) }\end{array}$ & & & & & & & \\
\hline Sarana & & & & 6.50 & & & \\
\hline $\begin{array}{l}\text { Layana } \\
\mathrm{n}(\mathrm{X} 2)\end{array}$ & ,748 & ,115 & ,742 & & ,000 & ,996 & 1,053 \\
\hline
\end{tabular}

a Dependent Variable: Kualitas Layanan (Z) Sumber: Output Spss Diolah (lihat lampiran 5) 
Berdasarkan hasil perhitungan dari pengaruh antar variabel kemampuan pegawai $\left(\mathrm{X}_{1}\right)$ dan sarana layanan $\left(\mathrm{X}_{2}\right)$ terhadap kualitas layanan $(\mathrm{Z})$, maka dapat disusun persamaan struktural untuk model analisis path tersebut sebagai berikut:

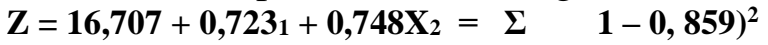

\section{Pengujian Hipotesis Struktur I}

Berdasarkan dari data hasil rekapitulasi uji regresi tersebut, maka dapat diolah hipotesis yang telah diajukan dalam penelitian ini. Untuk mengetahui akan pengujian hipotesis pertama secara parsial terlebih dahulu harus diketahui akan $t_{\text {tabel }}$ dengan cara mendapatkan $t_{\text {tabel }}$ digunakan tabel distribusi t untuk tingkat signifikasi 5\% dengan Degrees of Freedom $(\mathrm{df})=$ n-k maka di dapat df adalah (983 )= 95 dengan demikian $t_{\text {tabel }}$ adalah sebesar 1,646. Berdasarkan data tersebut dapat digambarkan hasil pengujian hipotesis pertama ini dengan uraian, yaitu:

\section{1) Pengujian Hipotesis Pertama (H1)}

Kemampuan pegawai berpengaruh signifikan terhadap kualitas layanan pada Kelurahan Batu Piring Kecamatan Paringin Selatan Kabupaten Balangan

Variabel kemampuan pegawai $\left(\mathrm{X}_{1}\right)$ mempunyai pengaruh signifikan dan positif terhadap kualitas layanan $(Z)$, dimana thitung lebih besar dari $t_{\text {tabel }}$ seperti $t_{\text {hitung }}=6,075>$ ttabel $=1,646$ dengan signifikasi $\mathrm{P}=0,001<0,05$. Besar pengaruh langsung antara variable kemampuan pegawai $\left(X_{1}\right)$ tersebut mempunyai hubungan yang signifikan terhadap variabel kinerja pegawai (Z), hal itu dapat dilihat dari nilai beta atau Standardized Coefficient yaitu sebesar 0,720, artinya kemampuan pegawai $\left(\mathrm{X}_{1}\right)$ mempunyai pengaruh signifikan secara langsung terhadap kualitas layanan (Z) sebesar $72 \%$, berarti hipotesis pertama terkait variabel kemampuan pegawai mempunyai pengaruh signifikan dan positif terhadap kualitas layanan $(\mathrm{Z})$,diterima.

\section{2) Pengujian Hipotesis Kedua (H2)}

Sarana layanan berpengaruh signifikan terhadap kualitas layanan pada Kelurahan Batu Piring Kecamatan Paringin Selatan Kabupaten Balangan. Variabel sarana layanan $\left(\mathrm{X}_{2}\right)$ mempunyai pengaruh signifikan dan positif terhadap kualitas layanan $(\mathrm{Z})$, dimana $\mathrm{t}_{\text {hitung }}$ lebih besar dari $t_{\text {tabel }}$ seperti $t_{\text {hitung }}=6,504>\mathrm{t}_{\text {tabel }}=1,646$ dengan signifikasi $\mathrm{P}=0,000<0,05$. Sedangkan besar pengaruh langsung antara variabel sarana layanan $\left(\mathrm{X}_{2}\right)$ tersebut mempunyai hubungan yang signifikan terhadap kualitas layanan (Z), hal itu dapat dilihat dari nilai beta atau Standardized Coefficient yaitu sebesar 0,742, artinya sarana layanan $\left(\mathrm{X}_{2}\right)$ mempunyai pengaruh signifikan secara langsung terhadap kualitas layanan $(Z)$ sebesar $74,2 \%$, yang berarti hipotesis yang menyatakan bahwa variabel sarana layanan $\left(\mathrm{X}_{2}\right)$ mempunyai pengaruh signifikan dan positif terhadap kualitas layanan (Z), diterima.

\section{Pengujian Hipotesis Struktur II}

Untuk pembuktian hipotesis berikutnya yang telah diajukan beserta analisis dalam penelitian ini dari hasil pengolahan data sebagai berikut:

\section{Tabel 5.18}

Hasil Analisis Path dengan Metode Regresi BergandaUji Struktur IICoefficients(a)

\begin{tabular}{|c|c|c|c|c|c|c|c|}
\hline & \multicolumn{2}{|c|}{$\begin{array}{c}\text { Unstandardized } \\
\text { Coefficients }\end{array}$} & \multirow{2}{*}{$\begin{array}{c}\begin{array}{c}\text { Standardiz } \\
\text { ed } \\
\text { Coefficient } \\
\text { s }\end{array} \\
\text { Beta }\end{array}$} & \multirow[b]{2}{*}{$\mathrm{t}$} & \multirow[b]{2}{*}{ Sig } & \multicolumn{2}{|c|}{$\begin{array}{c}\text { Collinearity } \\
\text { Statistics }\end{array}$} \\
\hline & B & $\begin{array}{l}\text { Std. } \\
\text { Error }\end{array}$ & & & & $\begin{array}{c}\text { Tolera } \\
\text { nce }\end{array}$ & VIF \\
\hline (Constant) & 24,391 & 4,023 & & 6,062 & $\begin{array}{r}, 00 \\
0\end{array}$ & & \\
\hline $\begin{array}{l}\text { Kemampua } \\
\text { n Pegawai } \\
\text { (X1) }\end{array}$ & ,694 & ,120 & 693 & 5,783 & $\begin{array}{r}, 00 \\
2\end{array}$ & ,990 & $\begin{array}{l}1,0 \\
25\end{array}$ \\
\hline $\begin{array}{l}\text { Sarana } \\
\text { Layanan } \\
\text { (X2) }\end{array}$ & ,760 & ,118 & ,759 & 6,440 & $\begin{array}{r}, 00 \\
1\end{array}$ & ,993 & $\begin{array}{r}1,0 \\
99\end{array}$ \\
\hline $\begin{array}{l}\text { Kualitas } \\
\text { Layanan } \\
(\mathrm{Z})\end{array}$ & ,838 & ,114 &, 831 & 7,350 & $\begin{array}{r}, 00 \\
0\end{array}$ & ,997 & $\begin{array}{r}1,1 \\
13\end{array}$ \\
\hline
\end{tabular}

a Dependent Variable: Kepuasan Masyarakat (Y)

Sumber : lampiran 5

Berdasarkan hasil perhitungan dari pengaruh antar variabel kemampuan pegawai $\left(X_{1}\right)$, sarana layanan $\left(\mathrm{X}_{2}\right)$ terhadap kualitas layanan $(\mathrm{Z})$ dan kepuasan masyarakat (Y), maka dapat disusun persamaan struktural untuk model analisis path tersebut sebagai berikut:

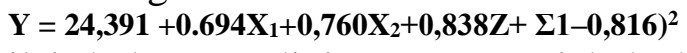

Menilai hubungan linier antar variabel dapat dilakukan membandingkan nilai thitung dengan langkah penentuan taraf signifikasi 0,05 dan derajat kebebasan (DK). Cara dengan membandingkan nilai $t_{\text {hitung }}$ dengan $t_{\text {table }}$ pada taraf nyata5\%. Jika $t_{\text {hitung }}>t$ table maka pengaruhnya signifikan. Untuk mendapatkan $t_{\text {tabel }}$ digunakan tabel distribusi t signifikasi 5\% dengan Degrees of Freedom $(\mathrm{df})=\mathrm{n}-\mathrm{k}$ maka d df adalah $(98-4)=$ 94 dengan demikian $t_{\text {tabel }}$ adalah sebesar 1,647. Hasil path analysis variabel X1, X2 dan X3 dan Z terhadap $\mathrm{Y}$, untuk melihat uji hipotesis tersebut, yaitu:

\section{1) Pengujian Hipotesis Ketiga(H3)}


Kemampuan pegawai berpengaruh signifikan terhadap kepuasan masyarakat pada Kelurahan Batu Piring Kecamatan Paringin Selatan Kabupaten Balangan

Hasil pengujian hipotesis ke tiga menunjukkan bahwa variabel keampuan pegawai $\left(\mathrm{X}_{1}\right)$ berpengaruh langsung terhadap kepuasan masyarakat (Y), dimana $t_{\text {hitung }}$ lebih besar dari tabel $\left(t_{\text {hitung }}=5,783>t_{\text {tabel }}=1,647\right)$, dengan signifikasi $\mathrm{P}=0,002<0,05$. Besar pengaruh langsung antara variabel kemampuan pegawai $\left(\mathrm{X}_{1}\right)$ tersebut mempunyai hubungan yang signifikan terhadap variabel kepuasan masyarakat (Y), hal itu dapat dilihat dari nilai beta atau Standardized Coefficient yaitu sebesar 0,693, artinya kemampuan pegawai $\left(\mathrm{X}_{1}\right)$ mempunyai pengaruh signifikan secara langsung terhadap kepuasan masyarakat (Y) sebesar 69,3\%. yang berarti hipotesis ke tiga yang menyatakan variabel kemampuan pegawai $\left(\mathrm{X}_{1}\right)$ mempunyai pengaruh signifikan dan positif terhadap kepuasan masyarakat (Y), diterima.

\section{2) Pengujian Hipotesis ke empat (H4)}

Sarana layanan berpengaruh signifikan terhadap kepuasan masyarakat pada Kelurahan Batu Piring Kecamatan Paringin Selatan Kabupaten Balangan. Hasil pengujian hipotesis ke lima menunjukkan bahwa variabel sarana layanan $\left(\mathrm{X}_{2}\right)$ berpengaruh langsung terhadap kepuasan masyarakat (Y),dimana $t_{\text {hitung }}$ lebih besar dari $t_{\text {tabel }}$ $\left.\left(t_{\text {hitung }}=6,440\right\rangle t_{\text {tabel }}=1,647\right)$, dengan signifikasi $\mathrm{P}=0,001<0,05$. Besar pengaruh langsung antara variable sarana layanan $\left(\mathrm{X}_{2}\right)$ tersebut mempunyai hubungan yang signifikan terhadap variabel kepuasan masyarakat (Y), hal itu dapat dilihat dari nilai beta atau Standardized Coefficient yaitu sebesar 0,759, artinya sarana layanan $\left(\mathrm{X}_{2}\right)$ mempunyai pengaruh signifikan secara langsung terhadap kepuasan masyarakat (Y) sebesar $75,9 \%$. yang berarti hipotesis ke empat yang menyatakan variabel sarana layanan $\left(\mathrm{X}_{2}\right)$ mempunyai pengaruh signifikan dan positif terhadap kepuasan masyarakat (Y), diterima.

\section{3) Pengujian Hipotesis ke lima (H5)}

Kualitas layanan berpengaruh signifikan terhadap kepuasan masyarakat pada Kelurahan Batu Piring Kecamatan Paringin Selatan Kabupaten Balangan Hasil pengujian hipotesis ke lima menunjukkan bahwa variabel kualitas layanan $(\mathrm{Z})$ berpengaruh langsung terhadap kepuasan masyarakat (Y) dimana $t_{\text {hitung }}$ lebih besar dari $t_{\text {tabel }}\left(t_{\text {hitung }}=7,350\right.$ > $\left.\mathrm{t}_{\text {tabel }}=1,647\right)$, dengan signifikasi $\mathrm{P}=0,000<0,05$. Besar pengaruh langsung antara variabel kualitas layanan $(Z)$ tersebut mempunyai hubungan yang signifikan terhadap variabel kepuasan kerja (Y), hal itu dapat dilihat dari nilai beta atau Standardized Coefficient yaitu sebesar 0,831, artinya kualitas layanan (Z) mempunyai pengaruh signifikan secara langsung terhadap kepuasan masyarakat (Y) sebesar $83,1 \%$. yang berarti hipotesis ke lima yang menyatakan variabel kualitas layanan (Z) mempunyai pengaruh signifikan dan positif terhadap kepuasan masyarakat (Y), diterima.

\section{Pengujian Determinasi}

Untuk melihat besar keofesien diterminan dapat dilihat dari nilai $\mathrm{R}^{2}$ yang mana untuk struktur pertama $\mathrm{R}^{2}$ sebesar 0,793 dan struktur kedua nilai $\mathrm{R}^{2}$ sebesar 0,777 disini bisa dijelaskan, bahwa :

$$
\begin{aligned}
& \epsilon_{1}=1-0,793=0,207 \\
& \epsilon_{2}=1-0,777=0,223 \\
& R^{2}=(0,207)^{2} X(0,223)^{2} \\
& R^{2}=1-0,042 \times 0,049 \\
& R^{2}=1-0,002058 \\
& R^{2}=0,99
\end{aligned}
$$

Angka 0,99 mempunyai makna sebagian besarnya variabel bebas dan perantara mempunyai pengaruh signifikan terhadap variabel terikat karena nilai $\mathrm{R}^{2}$ yakni 0,99 mendekati nilai 1 .

\section{Pengujian Pengaruh Secara Langsung (direct effect)}

Dapat disimpulkan akan pengaruh langsung (direct effect) antara variabel tersebut, yaitu

a. Kemampuan pegawai berpengaruh signifikan terhadap kualitas layanan pada Kelurahan Batu Piring Kecamatan Paringin Selatan Kabupaten Balangan sebesar 0,720 atau $72 \%$.

b. Sarana layanan berpengaruh signifikan terhadap kualitas layanan pada Kelurahan Batu Piring Kecamatan Paringin Selatan Kabupaten Balangan sebesar 0,742 atau 74,2\%

c. Kemampuan pegawai berpengaruh signifikan terhadap kepuasan masyarakat pada Kelurahan Batu Piring Kecamatan Paringin Selatan Kabupaten Balangan sebesar 0,693 atau 69,3\%

d. Sarana layanan berpengaruh signifikan terhadap kepuasan masyarakat pada Kelurahan Batu Piring Kecamatan Paringin Selatan Kabupaten Balangan sebesar 0,759 atau 75,9\%

e. Kualitas layanan berpengaruh signifikan terhadap kepuasan masyarakat pada Kelurahan 
Batu Piring Kecamatan Paringin Selatan Kabupaten Balangan sebesar 0,831 atau 83,1\%

\section{Pengujian Pengaruh Secara tidak Langsung (Indirect Effect atau IE)}

Selain itu untuk melihat pengaruh tidak langsung (Indirect Effect atau IE) terkait dengan variabel kemampuan pegawai $\left(\mathrm{X}_{1}\right)$, sarana layanan $\left(\mathrm{X}_{2}\right)$, terhadap kualitas layanan (Z) dan kepuasan masyarakat (Y), yaitu sebagai berikut:

1. Untuk melihat besar pengaruh tidak langung dari variabel bebas kemampuan pegawai $\left(\mathrm{X}_{1}\right)$ terhadap variabel terikat kepuasan masyarakat (Y) melalui intervening kualitas layanan (Z), dapat diperhitungkan: $\mathrm{PYX}_{1} \times \mathrm{PZY}=(0,720 \mathrm{x}$ $0,831)=0,598$. Berdasarkan perhitungan tersebut dapat disimpulkan bahwa pengaruh tidak langung dari variabel bebas kemampuan pegawai $\left(\mathrm{X}_{1}\right)$ terhadap variabel terikat kepuasan masyarakat (Y) melalui intervening kualitas layanan (Z) adalah sebesar 59,8\%.

2. Untuk melihat besar pengaruh tidak langung dari variabel bebas sarana layanan $\left(\mathrm{X}_{2}\right)$ terhadap variabel terikat kepuasan masyarakat (Y) melalui intervening kualitas layanan $(\mathrm{Z})$, dapat diperhitungkan: $\mathrm{PYX}_{2} \times \mathrm{PYZ}=(0,741$ $\mathrm{x} 0,831)=0,616$. Berdasarkan perhitungan tersebut dapat disimpulkan bahwa pengaruh tidak langung dari variabel bebas sarana layanan $\left(\mathrm{X}_{2}\right)$ terhadap variabel terikat kepuasan masyarakat (Y) melalui variabel intervening kualitas layanan ( $\mathrm{Z}$ ) adalah sebesar 61,6\%.Sehubungan dengan hal tersebut, maka dapat gambarkan model diagram jalurnya sebagai berikut:

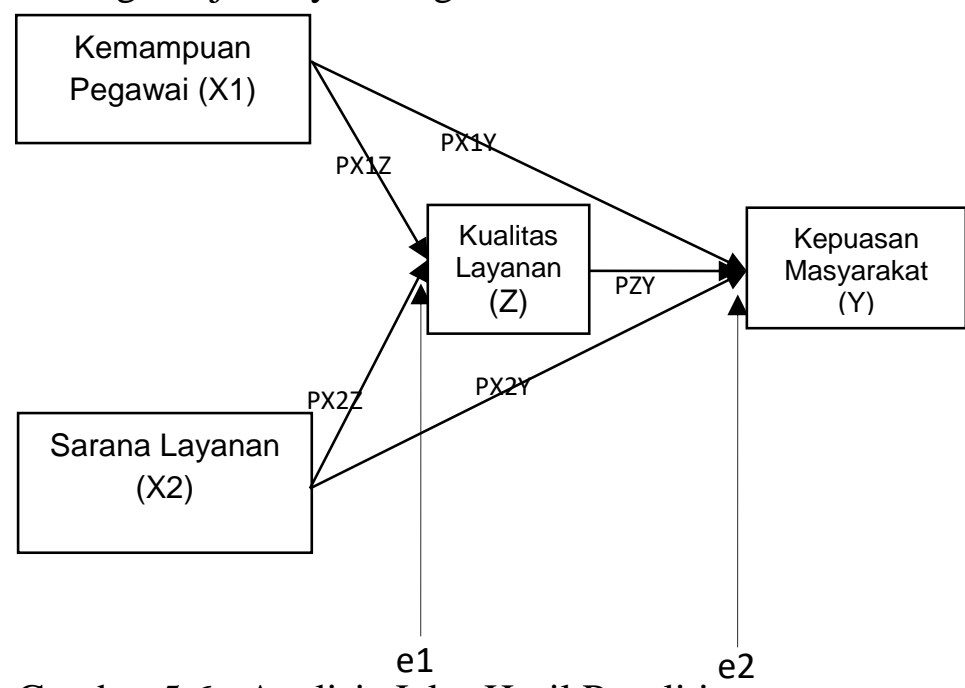

Gambar 5.6: Analisis Jalur Hasil Penelitian Sumber : data diolah

\subsection{Pembahasan}

1. Kemampuan pegawai berpengaruh signifikan terhadap kualitas layanan pada Kelurahan Batu Piring Kecamatan Paringin Selatan Kabupaten Balangan.

Hasil uji hipotesis pertama dinyatakan bahwa variabel kemampuan pegawai berpengaruh signifikan terhadap kualitas layanan pada Kelurahan Batu Piring Kecamatan Paringin Selatan Kabupaten Balangan, hasil penelitian ini sejalan dengan peneltian yang telah Anwar dilakukan oleh Zain, 2014, yang dalam penelitiannya mengungkapkan bahwa kemampuan pegawai berpengaruh signifikan terhadap kualitas layanan. Hasil penelitian ini pun sejalan dengan teori yang dikemukakan oleh Winardi (2010:88) kemampuan kerja secara umum diartikan sebagai kecakapan, keterampilan, kemampuan. Kata dasarnya sendiri yaitu kompeten, tentu saja berarti cakap, mampu, atau terampil. Pada konteks manajemen SDM istilah kompetensi mengacu kepada atribut /karakteristik seseorang yang membuatnya berhasil dalam pekerjaannya. Selain itu menyatakan bahwa perubahan kemampuan, keterampilan, dan sikap yang positif merupakan salah satu ukuran keberhasilan peserta pengembangan organisasi. Sejalan dengan hal tersebut, maka hendaknya Kelurahan Batu Piring Kecamatan Paringin Selatan Kabupaten Balangan, perlu meningkatkan kembali kemampuan pegawai baik itu kemampuan tentang pengetahuan dan keterampilan dalam pemahaman secara luas yang mencakup segala hal yang pernah diketahui yang berkaitan dengan tugas-tugas individu didalam organisasi, mening Kepuasan Kerja psikona $\underset{(\mathrm{Y})}{\mathrm{K}} \mathrm{Kepuasan \text {Kerja }}$ ik pelaksanaan kerja tertentuـ_ lengan tugas individu dalam suatu organisasi serta meningkatkan kemampuan sikap pegawai, menyangkut sikap berdisiplin, sikap profesional dalam bekerja serta sikap melayani terhadap masyarakat.

2. Sarana layanan berpengaruh signifikan terhadap kualitas layanan pada Kelurahan Batu Piring Kecamatan Paringin Selatan Kabupaten Balangan.

Hasil uji hipotesis kedua dinyatakan bahwa variabel sarana layanan berpengaruh signifikan terhadap kualitas layanan pada Kelurahan Batu Piring Kecamatan Paringin Selatan Kabupaten 
Balangan, hasil penelitian ini sejalan dengan peneltian yang telah Anwar dilakukan oleh Iwan Setiawan, 2015, yang menyatakan dalam penelitiannya bahwa sarana pelayanan berpengaruh signifikan terhadap kualitas pelayanan. Hasil penelitian ini pun sejalan dengan teori yang dikemukakan oleh Moenir (2012:119) pengertian sarana prasarana adalah segala jenis peralatan, perlengkapan kerja dan fasilitas yang berfungsi sebagai alat utama atau pembantu dalam pelaksanaan kerja dan juga dalam rangka kepentingan yang sedang berhubungan dengan organisasi kerja serta pelayanan.. Sejalan dengan hasil penelitian tersebut, hendaknya Kelurahan Batu Piring Kecamatan Paringin Selatan Kabupaten Balangan, dapat melengkapi sarana pelayanannya yang meliputi kerapian tempat kerja, ruang kerja yang rapi dan bersih, alat tranportasi bagi pelayanan darurat seperti ambulance, peralatan dan dan perlengkapan kantor seperti komputer dan lain-lain, serta sarana layana seperti ruang tunggu harus bersih dan nyaman, dan juga pelayanan cepat, lancar dan tertib dalam proses pekerjaan.

3. Kemampuan pegawai berpengaruh signifikan terhadap kepuasan masyarakat pada Kelurahan Batu Piring Kecamatan Paringin Selatan Kabupaten Balangan.Hasil uji hipotesis ketiga dinyatakan bahwa variabel kemampuan pegawai berpengaruh signifikan terhadap kepuasan masyarakat pada Kelurahan Batu Piring Kecamatan Paringin Selatan Kabupaten Balangan, hasil penelitian ini sejalan dengan peneltian yang telah Anwar dilakukan oleh Dewi Murni 2014, yang menyatakan dalam penelitiannya bahwa kemampuan pegawai berpengaruh signifikan terhadap kepuasan masyarakat. Hasil penelitian ini pun didukung pula oleh teori yang dikemukakan oleh Muzzakir. (2013:77) kemampuanadalah aktivitas seseorang untuk menghasilkan pada tingkat kepuasan ditempat kerja, termasuk diantaranya kemampuan seseorang untuk mentransfer dan mengaplikasikan keterampilan dan pengatahuan tersebut dalam situasi yang baru dan meningkatkan manfaat yang disepakati. Selain itu kemampuan juga menunjukkan karakteristik pengetahuan dan keterampilan yang dimiliki atau dibutuhkan oleh setiap individu untuk meningkatkan mereka untuk melakukan tugas dan tanggung jawab serta kepuasan dalam bekerja, sehingga mereka secara efektif dan meningkatkan standar kualitas profesional dalam pekerjaan mereka.Sehubungan dengan hal itulah, maka Kelurahan Batu Piring Kecamatan Paringin Selatan Kabupaten Balangan perlu meningkatkan kembali kemampuan pegawai agar dalam memberikan pelayanan dapat lebih maksimal dan hasil kerja menjadi baik sesuai dengan harapan, sehingga masyarakat yang mendapatkan pelayanan dari pegawai yang mempunyai kemampuan dalam bekerja ini akan merasa puas, untuk itu pihak instansi jangan bosan-bosannya untuk melakukan pelatihan dan memberikan program beajar atau tugas belajar kepada setiap pegawainnya, agar pegawai mempunyai kemampuan lebih baik lagi.

4. Sarana layanan berpengaruh signifikan terhadap kepuasan masyarakat pada Kelurahan Batu Piring Kecamatan Paringin Selatan Kabupaten Balangan.

Hasil uji hipotesis keempat dinyatakan bahwa variabel sarana layanan berpengaruh signifikan terhadap kepuasan pasien pada Kelurahan Batu Piring Kecamatan Paringin Selatan Kabupaten Balangan, hasil penelitian ini sejalan dengan peneltian yang telah dilakukan oleh Iwan Setiawan, 2015, yang menyatakan bahwa sarana pelayanan berpengaruh signifikan terhadap kepuasan masyarakat, dan sejalan pula dengan teori yang dikemukakan oleh Menurut Moenir (2012:121) menjelaskan fungsi utama dari sarana layanan, yaitu sebagai berikut mempercepat proses pelaksanaan pekerjaan sehingga mampu menghemat waktu, meningkatkan produktivitas baik barang maupun jasa, hasil kerja lebih berkualitas serta terjamin, lebih sederhana atau memudahkan dalam gerak para pengguna atau pelaku, ketetapan susunan stabilitas pekerja lebih terjamin, menimbulkan rasa kenyamanan bagi orang-orang yang berkepentingan dan menimbulkan rasa puas pada roang-orang yang berkepentingan yang mempergunakannya.Sejalan dengan hal tersebut hendaknya pihak Kelurahan Batu Piring Kecamatan Paringin Selatan Kabupaten Balangan dapat fokus dalam meningkatkan sarana pelayanan ini dengan melengkapi dan memberikan yang terbaik bagi masyarakat, baik melengkapi aspek sumber daya manusia yang 
handal dalam memberikan pelayanan, sistem pelayanan yang tidak berbelit-belit maupun sarana pelayanan yang lengkap seperti fasilitas ruang tunggu yang nyaman, dapat memberikan layanan satu pintu agar mempermudah urusan masyarakat.

5. Kualitas layanan berpengaruh signifikan terhadap kepuasan masyarakat pada Kelurahan Batu Piring Kecamatan Paringin Selatan Kabupaten Balangan.

Hasil uji hipotesis kelima dinyatakan bahwa variabel kualitas layanan berpengaruh signifikan terhadap kepuasan pasien pada Kelurahan Batu Piring Kecamatan Paringin Selatan Kabupaten Balangan, hasil penelitian ini sejalan dengan peneltian yang telah dilakukan oleh Setiawan, 2015, yang menyatakan bahwa kualitas pelayanan berpengaruh signifikan terhadap kepuasan masyarakat demikian juga didukung oleh teori yang dikemukakan oleh Hanif, (2014:35) menjelaskan kualitas layanan adalah upaya pemenuhan kebutuhan yang dibarengi dengan keinginan konsumen serta ketepatan cara penyampaian agar dapat memenuhi harapan dan kepuasan masyarakat. Sejalan dengan hasil penelitian ini hendaknya pihak Kecamatan dapat meningkatkan kembali kualitas layanannya dengan cara :

a. Meningkatkan kualitas pelayanan berupa sarana fisik perkantoran, komputerisasi administrasi, ruang tunggu, tempat informasi. Indikatornya adalah penampilan petugas/aparatur dalam melayani masyarakat, kenyamanan tempat, kemudahan dalam proses pelayanan, kemudahan akses pelanggan dalam permohonan pelayanan dan penggunaan alat bantu dalam pelayanan lengkap.

b. Meningkatkan kemampuan dan keandalan untuk menyediakan pelayanan yang terpercaya. Indikatornya adalah kecermatan petugas dalam melayani, memiliki standar pelayanan yang jelas, kemampuan petugas/aparatur dalam menggunakan alat bantu dalam proses pelayanan dan keahlian petugas dalam menggunakan alat bantu dalam proses pelayanan.

c. Kesanggupan untuk membantu dan menyediakan pelayanan secara cepat dan tepat, serta tanggap terhadap keinginan konsumen. Indikatornya adalah merespon setiap pelanggan/pemohon yang ingin mendapatkan pelayanan, petugas/aparatur melakukan pelayanan dengan cepat, petugas/aparatur melakukan pelayanan dengan tepat dan cermat, petugas/aparatur melakukan pelayanan dengan waktu yang tepat dan semua keluhan pelanggan direspon oleh petugas

d. Meningkatkan kemampuan terhadap keramahan serta sopan santun pegawai dalam meyakinkan kepercayaan konsumen. Indikatornya adalah petugas memberikan jaminan tepat waktu dalam pelayanan, petugas memberikan jaminan biaya yang sesuai dalam pelayanan, petugas memberikan jaminan legalitas dalam pelayanan dan petugas memberikan kepastian biaya tanpa meminta uang muka.

e. Bersikap tegas tetapi penuh perhatian dari pegawai terhadap konsumen. Indikatornya adalah endahulukan kepentingan pelanggan/pemohon, petugas melayani dengan sikap ramah, petugas melayani dengan sikap sopan santun, petugas melayani dengan tidak diskriminatif (membeda-bedakan) dan petugas melayani dan menghargai setiap masyarakat.

\section{BAB VI PENUTUP}

\subsection{Kesimpulan}

1. Hasil uji hipotesis pertama dinyatakan bahwa variabel kemampuan pegawai berpengaruh signifikan terhadap kualitas layanan pada Kelurahan Batu Piring Kecamatan Paringin Selatan Kabupaten Balangan.

2. Hasil uji hipotesis kedua dinyatakan bahwa variabel sarana layanan berpengaruh signifikan terhadap kualitas layanan pada Kelurahan Batu Piring Kecamatan Paringin Selatan Kabupaten Balangan.

3. Hasil uji hipotesis ketiga dinyatakan bahwa variabel kemampuan pegawai berpengaruh signifikan terhadap kepuasan pasien pada Kelurahan Batu Piring Kecamatan Paringin Selatan Kabupaten Balangan.

4. Hasil uji hipotesis keempat dinyatakan bahwa variabel sarana layanan berpengaruh signifikan terhadap kepuasan masyarakat pada Kelurahan Batu Piring Kecamatan Paringin Selatan Kabupaten Balangan

5. Hasil uji hipotesis kelima dinyatakan bahwa variabel kualitas layanan berpengaruh signifikan terhadap kepuasan masyarakat 
pada Kelurahan Batu Piring Kecamatan Paringin Selatan Kabupaten Balangan

\subsection{Saran}

1. Hendaknya Kelurahan Batu Piring Kecamatan Paringin Selatan Kabupaten Balangan, perlu meningkatkan kembali kemampuan pegawai baik itu kemampuan tentang pengetahuan dan keterampilan dalam pemahaman secara luas yang mencakup segala hal yang pernah diketahui yang berkaitan dengan tugas-tugas individu didalam organisasi, meningkatkan keterampilan berupa kemampuan psikomotorik, dan teknik pelaksanaan kerja tertentu yang berkaitan dengan tugas individu dalam suatu organisasi serta meningkatkan kemampuan sikap pegawai, menyangkut sikap berdisiplin, sikap profesional dalam bekerja serta sikap melayani terhadap masyarakat.

2. Hendaknya Kelurahan Batu Piring Kecamatan Paringin Selatan Kabupaten Balangan, dapat melengkapi sarana pelayanannya yang meliputi kerapian tempat kerja, ruang kerja yang rapi dan bersih, alat tranportasi bagi pelayanan darurat seperti ambulance, peralatan dan dan perlengkapan kantor seperti komputer dan lain-lain, serta sarana layana seperti ruang tunggu harus bersih dan nyaman, dan juga pelayanan cepat, lancar dan tertib dalam proses pekerjaan juga perlu ditingkatkan.

3. Kelurahan Batu Piring Kecamatan Paringin Selatan Kabupaten Balangan perlu meningkatkan kembali kemampuan pegawai agar dalam memberikan pelayanan dapat lebih maksimal dan hasil kerja menjadi baik sesuai dengan harapan, sehingga masyarakat yang mendapatkan pelayanan dari pegawai yang mempunyai kemampuan dalam bekerja ini akan merasa puas, untuk itu pihak instansi jangan bosan-bosannya untuk melakukan pelatihan dan memberikan program belajar atau tugas belajar kepada setiap pegawainnya, agar pegawai mempunyai kemampuan lebih baik lagi.

4. Hendaknya pihak Kelurahan Batu Piring Kecamatan Paringin Selatan Kabupaten Balangan dapat fokus dalam meningkatkan sarana pelayanan ini dengan melengkapi dan memberikan yang terbaik bagi masyarakat, baik melengkapi aspek sumber daya manusia yang handal dalam memberikan pelayanan, sistem pelayanan yang tidak berbelit-belit maupun sarana pelayanan yang lengkap seperti fasilitas ruang tunggu yang nyaman, dapat memberikan layanan satu pintu agar mempermudah urusan masyarakat.

5. Hendaknya pihak Kelurahan Batu Piring Kecamatan Paringin Selatan Kabupaten Balangan dapat meningkatkan kembali kualitas layanannya dengan cara meningkatkan kualitas pelayanan berupa sarana fisik perkantoran, meningkatkan kemampuan dan keandalan untuk menyediakan pelayanan yang terpercaya, Sanggup untuk membantu dan menyediakan pelayanan secara cepat dan tepat, serta tanggap terhadap keinginan konsumen, meningkatkan kemampuan terhadap keramahan serta sopan santun pegawai dalam meyakinkan kepercayaan konsumen dan bersikap tegas tetapi penuh perhatian dari pegawai terhadap masyarakat.

\section{DAFTAR PUSTAKA}

Abdurrachman, 2013, Pengantar Ilmu Manajemen, Gramedia Pustaka Utama (GPU), Jakarta

Arikunto. Suharsimi, 2012, Metode Penelitian dan Aplikasi Stasistik, PT, Rajwali Press, Jakarta

Amir.Hamzah, 2013, Manajemen Pelayanan, Bumi Daya, Jakarta

Anwar Zain, 2014, Pengaruh Kemampuan Pegawai dan Sarana Pelayanan Terhadap Kualitas Layanan dan Kepuasan Masyarakat pada Kantor Kecamatan MungkidKabupaten Magelang.Fakultas Ekonomi Universitas Negeri Yogyakarta

Chandra, 2013, Unsur-unsur Manajemen Perusahaan, Buana Putra, Surabaya

Dharma. Satria, 2015, Manajemen SDM, PT Indah Media, Bandung

Darsuni, 2013, Manajemen dan Perilaku Keorganisasian, Bumi Aksara, Jakarta

Darmawan, 2011, Kualitas Pelayanan Publik, PT. Rajawali Press, Jakarta

Dewi Murni 2014, Pengaruh Kemampuan Pegawai, Sarana dan Prasarana Kerja dan Kualitas Layanan Rumah Sakit Terhadap 
Kepuasan Masyarakat pada RSUD Ulin Banjarmasin, nlam, Banjarmasin

Eko. Darmono, 2011, Manajemen Pelayanan Publik, PT.Grafika Media, Jakarta

Erlinda Lestari,, 2011, Proses Pengelolaan Manajemen Pegawai, Liberty, Jakarta

Ghozali. Imam,2013, Metodologi Penelitian, Rineka Cipta, Jakarta

Hardiansyah 2011, Manajemen Pelayanan Publik, Ghalia Indonesia, Jakarta

Handoko. T. Hani, 2012, Manajemen SDM dan Kepersonalian, Edisi revisi BPFE, Yogyakarta

Hadipranata, 2010, Peningkatan Kualitas Pelayanan Publik di Indonesia, Pradya Paramita Jakarta

Hendrik, 2010, Manajemen Pelayanan Publik, Rineka Cipta, Jakarta

Hanif, 2014. Manajemen Perilaku dan Mutu Pelayanan, Jakarta : Bumi Aksara

Iwan Setiawan, 2015, Pengaruh kemampuan Pegawai dan Sarana Pelayanan kerja terhadap Kualitas Pelayanan dan Kepuasan Masyarakat pada Kantor Kelurahan Banjarmasin Selatan, Unlam, Banjarmasin

Jumni, 2011, Manajemen Pelayanan Jasa, Rineka Cipta, Jakarta

Juanandi, 2014, Manajamen Kerja dan Keorganisasian, Balai Pustaka, Jakarta

Komariah, 2012, Manajemen Sarana Dan Prasana Perusahaan, Buku I, Alfabetha, Bandung

Loina. Indahdarini, 2013, Manajemen dan Produktivitas Kerja, PT. Rajawali Press, Jakarta

Lukman Nul Hakim, 2016, Pengaruh Sarana

Prasarana, dan Kemampuan Pegawai dan Kualitas Pelayanan Terhadap Kepuasan Masyarakat pada Kantor Camat Bekasi, Universitas Mercu Buana, Bekasi

Murniaty, 2013, Manajemen Sarana Prasarana Perusahaan, Rajagrafido Persada, Jakarta

Muzzakir. Abdullah, 2013, Manajemen Produktivitas Kerja, Salemba, Jakarta

Mulyasa, 2015, Evaluasi dan Supervisi Fasilitas Organisasi, Gramedia Indonesia, Jakarta

Mangkunegara. A.A. Anwar Prabu, 2012, Manajemen Sumber daya Manusia, BPFE, Yogyakarta

Makmun, 2012, Manajemen Bisnis dan Keorganisasian, Bumi Aksara, Jakarta
Moenir, AS. 2012. Manajemen Pengembangan Karyawan,: Pradya Paramita Jakarta

Muhdari, 2011, Manajemen Pelayanan dan Jasa, Rineka Cipta, Jakarta

Muchtarman, 2012, Delivering Quality Service.Erlangga, Jakarta

Nitisemito. Alex, 2012, Manajemen SDM dan Kepersonalian, Ghalia Indonesia, Jakarta

Nova, Nursanty, 2013, Manajemen Sumber Daya Manusia, Balai Pustaka, Jakata

Ngaliban. Abdi, 2010, Manajemen Organisasi Manufaktur, Rineka Cipta, Jakarta

Peraturan Menteri No. 96 Tahun 2012, pelayanan publik, Jakarta

Permen No. 16 Tahun 2014 menjelaskan rancangan Standar Pelayanan, Jakarta

Peraturan Pemerintah republik Indonesia Nomor 73 Tahun 2005 tentang Kelurahan, Jakarta

Rasyid. Abdul, 2013, Manajemen Sumber Daya Manusia (MSDM), Jilid I, Pustaka, Jakarta

Rivai, Veithzal, 2012, Manajemen Sumber Daya Manusia Untuk Perusahaan, Edisi Kedua, PT. Raja Grafindo Persada Jakarta

Rahmat, 2012, Manajemen Sumber Daya Manusia, Andi Publisher, Bandung

Resimin. Niar, 2013, Manajemen SDM, Rineka Cipta, Jakarta

Royan. Ahmad, 2013, Manajemen Ketenagakerjaan, Rineka Cipta, Jakarta

Sumarsono, 2012, Manajemen Perkantoran, Bumi Aksara, Jakarta

Sihotang, 2012, Manajemen SDM dan Kepegawaian, Gramedia Widiasarana Indonesia, Jakarta

Soenarso, 2012, Manajemen Perusahaan, Agro media, Yogyakarta

Sami. S, 2010, Pelayanan yang Memuaskan, Liberty, Jakarta

Soelarso, 2014, Manajemen Perlengkapan dan Peralatan Kerja, Rineka Cipta, Jakarta

Sutarjo, 2013, Menguak Kemampuan Pekerja Migran (Buku Ajar), Gramedia Widiasarana Indonesia, Jakarta

Siregar, 2013, Azaz-azaz Pelayanan Publik, Rineka Cipta, Jakarta

Susilo, 2013, Manajemen Kepegawaian, Rineka Cipta, Jakarta 
Sugeng, 2015, Manajemen Sumber Daya Manusia, Buku II, Media Pustaka, Surabaya

Sujatmo, 2015, Manajemen Perusahaan, Salemba, Jakarta

Umar. Hasan, 2013, Perilaku Organisasi, Graha Media, Jakarta

Wahjosumidjo, 2014, Manajemen Fasilitas Kerja, Jilid IV, Liberty, Jakarta

Wibowo,2013, Manajemen Kualitas Dalam Industri Jasa, Cetakan Pertama, Gramedia Pustaka Utama, Jakarta

Widya Hayati, 2014, Manajemen dan Kepegawaian, Elexmedia Komputindo, Jakarta

Winardi, 2010, Manajemen, Buana Karya, Bandung 